\title{
Verticillium Wilt on Rose Plants in Minia Governorate and its Control
}

Hanaa A.H. Armanious

Plant Pathol. Dept., Fac. Agric., Minia Univ., Egypt.

Tine isolates of Verticillium dahliae, $\left(\mathrm{VD}_{1}-\mathrm{VD}_{9}\right)$ were 1 isolated from roots and stems of wilted rose plants (1-2 years old) grown in Minia and Abo-Qurqas counties, Minia Governorate during summer, 2012. All isolates were able to induce wilt symptoms with different degrees of vascular discoloration on rose plants through 60 - 90 days after planting. The maximum percentages $(100 \%)$ of wilted plants were obtained due to using isolates $\mathrm{VD}_{1}, \mathrm{VD}_{2}$ and $\mathrm{VD}_{3}$ which were isolated from Minia county, followed by isolate $\mathrm{VD}_{8}$ which was isolated from Abo Qurqas county (91.7\%). All tested concentrations of Rizolex-T and Topsin-M decreased the linear growth of the four tested isolates. The fungitoxic effect was increased with increasing the fungicide concentration up to 400 ppm; that inhibited completely the growth of the tested fungi. Phos-root $\mathrm{X}$ and Formula $\mathrm{X}-1$ stimulated the growth of the four tested isolates at the lowest rates, whereas the highest level, 3 $\mathrm{ml} / \mathrm{l}$, decreased the growth than control. Two bioagents, i.e., $T$. viride and $B$. subtilis were able to inhibit the mycelial growth of all tested pathogenic isolates. B. subtilis was effective in reducing the growth of the tested isolates where it gave 64.8 and $85.9 \%$ inhibition comparing to $T$. viride. The tested fungicides with different concentrations reduced significantly the percentage of infected plants comparing with control. Rizolex- $\mathrm{T}$ was more effective than Topsin-M in their efficiency. The maximum reduction of Verticillium wilt disease was recorded with using $3 \mathrm{ml} / \mathrm{l}$ of Phos-Root $\mathrm{X}$ and $2 \mathrm{ml} / 1$ of Formula-X. Addition of the two tested bio agents one week before planting to soil significantly decreased the percentages of infected rose plants and disease severity under artificial infection with any of the tested isolates of Verticillium dahliae.

Keywords: Bioagents, formula X-1, phos-root X, rizolex-T, Topsin-M70 and Verticillium dahliae. 
Rose (Rosa gallica L.) is one of the most important ornamental plants belongs to the Family Rosaceae. Roses grow in gardens, offices and homes. They are known worldwide for their fragrant showy blooms. Rose was well known in Egypt since the ancient Egyptians. The cultivated area planted with rose in 2011 reached 132000 feddans, produced 131000 tons of flowers (Anonymous, 2012). Minia Governorate has the largest cultivated area with roses, which are used for several purposes in local markets and for exportation. Rose plants are attacked by many different pathogenic fungi during their different growth stages which frequently induce severe losses in their productivity (Horst, 1983 and Salamone et al., 2011). Barguil et al. (2009) observed severe stem rot and wilting of rose (Rosa spp.) seedlings in commercial fields in Brazil. Fusarium oxysporum was consistently isolated from infected scions and rootstocks.

Wilt symptoms on rose plants were visual during the summer season of 2012 and 2013 in different nurseries at Minia and Abou Qurqas counties. Verticillium wilt is one of soil borne diseases causing vascular wilt symptoms of many plants where it inhibits the plant ability to move water from soil to the foliage (Maruthachalam et al., 2011). This study aimed to throw the light on Verticillium wilt which attacks rose plants in Minia governorate as a new appeared problem. In addition, to control the disease using some different techniques.

\section{Materials and Methods}

\section{Sampling, isolation and identification:}

Samples of natural wilted rose plants grown in the experimental greenhouse of the Faculty of Agriculture, Minia University, in addition to those grown in the commercial nurseries in Abo-Qurqas and Minia districts were collected during summer season of 2012. The wilted rose samples were brought separately to the laboratory for diagnosis. The diseased samples were rinsed in sterilized distilled water, and then disinfected with ethanol $95 \%$. Small fragments of wilted rose roots and stems were cut aseptically and were placed on plates containing selective medium for isolation of Verticillium spp. as described by Aushor et al. (1975) or on PDA in Petri plates. Plates were incubated at $25^{\circ} \mathrm{C}$ for 7 days. The developed fungal growth was sub-cultured on sterilized PDA medium. The isolated fungi were purified using the hyphal tip or the single-spore techniques (Booth, 1971). The purified fungi were kept on PDA slants in the refrigerator at $5^{\circ} \mathrm{Cas}$ stock cultures for further studies. The established fungal isolates were identified on the basis of culture morphology and microscopic characteristics of microsclerotia production (Gilman, 1957 and Hawksworth and Talboys, 1970), and were further verified by the Division of Fungal Taxonomy Department, Plant Pathology Research Institute, Agriculture Research Center, Giza, Egypt. 


\section{Pathogenicity test:}

Pathogenicity trials of the tested Verticillium isolates were carried out in the greenhouse of Plant Pathology Department, Faculty of Agriculture, Minia University, using cuttings of rose (Rosa gallica var. Aegyptiaca), obtained kindly from Prof. Dr. Mahmoud Abdel Hady, Department of Ornamental Plants, Faculty of Agriculture, Minia University. Cuttings (about 15-25 cm long and 10-12 mm in diameter) were planted in sterilized clay pots $(30 \mathrm{~cm}$. in diameter $)$ containing autoclaved Nile loamy-clay soil infested with the different isolates, each alone. The basal portions of rose cuttings were surface sterilized (to exclude the probability of accidental infection with saprophytic rotted bacteria or fungi) by dipping in sodium hypochlorite $(2 \%)$ solution for two minutes then washed several times with sterilized water before planting in the pots.

\section{Fungal inoculation:}

The tested Verticillium isolates were cultured onto PDA medium in Petri plates $(9 \mathrm{~cm})$ at kept at $25^{\circ} \mathrm{C}$ in the dark for 3 days. Inocula of the isolated fungi were prepared, separately, on autoclaved barley grains (150 gm grains $+200 \mathrm{ml}$ water/ $500 \mathrm{ml}$ Erlenmeyer flask). Flasks were inoculated with $5 \mathrm{~mm}$ discs which were cut out with a sterile cork-borer from the advancing margins of the tested fungal cultures. Inoculated flasks were kept at $25^{\circ} \mathrm{C}$ for 15 days then used for soil infestation. Soil infestation was applied 7 days before planting, by thoroughly mixing of $2 \%$ inoculum (w/w) of each of the tested Verticillium isolates individually. The number of conidia in the filtered suspension was estimated with a haemocytometer slide where they adjusted to a concentration of $4 \times 10^{6}$ conidia $/ \mathrm{ml}$. The infested soil was irrigated daily till planting. Four pots were used as replicates for each treatment where 3 cuttings were planted in each pot. The check (control) treatment was pots amended with sterilized, uninoculated barley medium only. Pots were watered when necessary. Plants were regularly examined for any disease symptoms, but final results were recorded 60 days after planting by recording the number of diseased plants (DI,\%) and disease severity (DS,\%). Disease severity on the aboveground plant parts was evaluated according to the modified scale of Bejarano-Alcázar et al. (1996) based on the percentage of foliage affected with chlorosis, necrosis, wilting, defoliation, and the presence of discoloration in vascular tissue in the stem: $0=$ no symptoms; $1=1 \%$ to $33 \%$ foliage affected; $2=1 \%$ to $33 \%$ foliage affected with vascular discoloration; $3=34 \%$ to $66 \%$ foliage affected; $4=$ $34 \%$ to $66 \%$ foliage affected with vascular discoloration; $5=67 \%$ to $100 \%$ foliage affected; $6=67 \%$ to $100 \%$ foliage affected with vascular discoloration; and $7=$ dead plant. Each plant was severed at the crown and cut longitudinally to assess the presence of vascular discoloration. The percentage of disease severity (DS, \%) was calculated according to the following formula:

Egypt. J. Phytopathol., Vol. 44, No. 2(2016) 
DS, $\%=\frac{1 \mathrm{xN}_{1}+2 \mathrm{xN}_{2}+3 \mathrm{xN}_{3}+\ldots \ldots .7 \mathrm{xN}_{7}}{7 \mathrm{x} \mathrm{N}} \times 100$

Where,

$\mathrm{N}_{1}, \mathrm{~N}_{2}, \mathrm{~N}_{3}, \ldots . \mathrm{N}_{7}$ are numerical values of the grade as in the mentioned scale, $\mathrm{N}=$ Total number of used plants and 7 is the maximum value of the scale.

Re-isolation was carried out from diseased cuttings to satisfy Koch's postulates.

\section{In vitro trails:}

These experiments were carried out to study the effect of some bio antagonists, nutrients and fungicides on growth of the tested Verticilliumisolates, the instant ofVerticilliumwilt on rose plants in vitro. The used isolates in these experiments were mostly those which proved to be highly pathogenic to rose plants, viz.isolates 1 and 2. In the following experiments, mycelial growth was measured as criterion for evaluating the effect of treatment. Except where otherwise mentioned, all experiments were performed on PDA medium. The $\mathrm{pH}$ value of the medium was adjusted before sterilization to $\mathrm{pH} 7$ using $0.1 \mathrm{~N} \mathrm{NaOH}$ or $0.1 \mathrm{~N} \mathrm{HCl}$. Media were autoclaved (for 15 minutes at $1 / 2 \mathrm{~kg} / \mathrm{cm}^{3}$ and then inoculated with $5 \mathrm{~mm}$ discs cut out with a sterile cork-borer from the advancing margins of the fungal cultures to be tested. Three plates were used as replicates per each treatment.

\subsection{Effect of different chemical compounds on growth of the tested fungi:}

The promoting or inhibitory effect of two commercial nutrient compounds (Formula X-1 and Phos-Root-X) and two fungicides (Topsin M-70 and Rizolex-T) on the linear growth of the rose wilt pathogen was evaluated. Four concentrations of each nutrient compound (1- the recommended dose, 2- half of the recommended dose, 3-1.5 of the recommended dose, and 4- two-folds of the recommended dose; Table 4) and four concentrations of each of the tested fungicide $(25,50,100$ and 200 $\mathrm{ppm})$ were prepared in accordance to the previously calculated volume of autoclaved PDA.The tested chemical compounds were kindly obtained from Union for Agricultural Development (UAD) Company, Cairo, Egypt.

Nutrient solutions were sterilized using Zeits filter. The solution of each concentration of the tested compound was added to conical flask $(100 \mathrm{ml})$ containing $40 \mathrm{ml}$ sterilized PDA medium before solidification to obtain the proposed concentration and shake gently, then dispensed into sterilized 4 Petri dishes $(9 \mathrm{~cm}$ in diam.). Petri dishes were individually inoculated with equal discs $(5 \mathrm{~mm})$ taken from 7-day-old cultures of the tested fungal isolates, then incubated at $25^{\circ} \mathrm{C}$ and examined daily. Petri dishes free of the tested compounds were served as control. The average of linear growth was measured when radial growth in any treatment or control 
reached its maximum, and the percentages of stimulation or reduction of growth were calculated

Table 1. Trade name, active ingredient and manufacturer of the used chemical compounds

\begin{tabular}{|c|c|c|c|}
\hline Trade name & \multicolumn{2}{|c|}{ Active ingredient } & Manufacturer \\
\hline Formula X-1 & $\begin{array}{c}\text { Chelated Zinc } \\
\text { Molibdinium } \\
\mathrm{Cu} \\
\text { Salicylic acid } \\
\text { Free amino acids (Glutam } \\
\text { L-proline and Meth } \\
\end{array}$ & $\begin{array}{c}2.5 \% \\
0.03 \% \\
0.04 \% \\
5.0 \% \\
\text { acid,Treptophan, } \\
\text { ine) } 10.0 \% \\
\end{array}$ & UAD, Egypt \\
\hline Phos-Root-X & $\begin{array}{l}\text { Free amino acids } \\
\text { Poly ethyl Glycole } \\
\text { Phosphore }\left(\mathrm{P}_{2} \mathrm{O}_{5}\right) \\
\text { Organic } \mathrm{N} . \\
\mathrm{Cu}\end{array}$ & $\begin{array}{c}1500 \mathrm{ppm} \\
0.01 \% \\
20.0 \% \\
3.0 \% \\
0.3 \%\end{array}$ & UAD, Egypt \\
\hline Rizolex-T & $\begin{array}{r}\text { Toclofos-m } \\
O \text {-(2,6-dichloro-4-n } \\
O \text {-O-dimethyl phosph } \\
\text { Other ingredie }\end{array}$ & $\begin{array}{l}y l \\
\text { hylphenyl) } \\
\text { thioate } 42 \% \\
58 \% \\
\end{array}$ & $\begin{array}{c}\text { Sumitomo } \\
\text { Chemical } \\
\text { Company, Ltd., } \\
\text { Valent, USA, Co. }\end{array}$ \\
\hline $\begin{array}{c}\text { Topsin M } \\
70 \mathrm{WP}\end{array}$ & $\begin{array}{l}\text { Thiophanate- } \\
\text { Dimethyl[1,2-phe } \\
\text { (iminocarbonotl } \\
\text { (carbomate) } \\
\text { Other ingredients }\end{array}$ & $\begin{array}{l}\text { thyl } \\
\text { lene)-bis } \\
\text { yl)] bis } \\
70 \% \\
30 \%\end{array}$ & $\begin{array}{c}\text { Nippon Soda } \\
\text { Co., Ltd., USA. }\end{array}$ \\
\hline
\end{tabular}

4.2. Efficacy of some antagonists in controlling Verticillium wilt pathogen in vitro:

Two antagonistic agents, i.e. Trichoderma viride and Bacillus subtilis, were isolated from rhizosphere of potato plants, purified and identified by Hassan (2013) and were used herein. Bioagents were grown on PDA and nutrient glucose agar medium (NCA), respectively, and then incubated at $25^{\circ} \mathrm{C}$ for 6 - or 2- days, respectively, for using as inocula. The antagonistic effects of the used bioagents were performed according to the method adopted by Bell et al. (1982) and Ferreira et al. (1991). A disc (5mm in diameter) from the culture of $T$. viride, or a loop from B. subtilis growth were used to inoculate PDA or nutrient glucose agar media, respectively, in one side of the Petri plates while opposite side was inoculated with the pathogen. Inoculated plates were incubated at $25^{\circ} \mathrm{C}$. Three replicates were used for each bioagent and also for each pathogen. Inoculated plates withthe pathogen

Egypt. J. Phytopathol., Vol. 44, No. 2(2016) 
only were used as control. Two to five days past inoculation, the linear growth of the pathogen was measured. The inhibition percent of growth was calculated as following:

Growth in control - growth in treatment

Growth inhibition $(\%)=\frac{\text { Growth in control }}{5 .} 100$

\section{Greenhouse experiments:}

These experiments were conducted in a trial to find out the most unfavorable conditions for development of rose wilt. Pot experiments were carried out in the open experimental field of the Plant Pathology Department, Faculty of Agriculture, Minia University, during seasons 2013 and 2014. In these experiments, sterilization of pots (30 cm in diameter), soil, preparation of inocula and soil infestation with the desired inoculum, preparation of rose cuttings and time of soil infestation ( 7 days before planting) and replications (4 pots each containing 3 cuttings of rose; $R$. gallica var. Aegyptiaca) were made as described before in pathogenicity test. Soil moisture was adjusted to $75 \%$ field capacity. Nile loamy soil was used. The average percentages of both wilted plants (DI \%) and disease severity (DS \%) of each treatment were calculated and data were statistically analyzed.

\subsection{Effect of different nutrient compounds on rose wilt disease incidence:}

Pot experiment was carried out to study the effect of two commercial nutrient compounds, i.e. Phos-Root $-\mathrm{x}$ and Formula $\mathrm{X}-1$ (registered at Ministry of Agriculture under numbers 7328 and7321, respectively), on the control of the disease. The tested commercial formula was used at half, 2-folds and the recommendeddose $(900 \mathrm{ml} / 600 \mathrm{~L}$ water and $600 \mathrm{ml} / 600 \mathrm{~L}$ water for Phos-Root-X and Formula X-1, respectively). The bases of experimental cuttings were soaked for 12 hours in aqueous solutions of the compounds to be tested. Distilled water free of compounds was used for treating control cuttings. Treated and untreated cuttings were planted in previously infested soil with the highly pathogenic isolates of the rose wilt pathogen. Percentages of disease incidence and disease severity were calculated, 60 days past planting.

5.2. Efficiency of some fungicides in controlling Verticillium wilt of rose:

Two commercial fungicides, namely Rizolex-T and Topsin M, were tested in pot experiment during 2013 and 2014 seasons as a foliar spraying or soil treatments. Three rates, $1 \frac{1}{2} \mathrm{~g} / \mathrm{l}, 3 \mathrm{~g} / \mathrm{l}$ (recommended dose) and $4 \frac{1}{2} \mathrm{~g} / \mathrm{l}$ of the active ingredient of each fungicide were used. The check treatment was performed by using sterilizeddistilled water. Cuttings were planted in potted soil infested with either of the tested isolates. The number of diseased plants and disease severity were recorded in the 4 replicates (each of 3 plants/a pot) of each treatment, 60 days after planting; at which time the maximum infection was appeared in the control (untreated) treatment.

Egypt. J. Phytopathol., Vol. 44, No. 2(2016) 
5.3. Effect of bioagents on rose wilt disease incidence:

An experiment was applied in the greenhouse to study the effect of soil infestation either with Trichoderma viride or Bacillus subtilis on the incidence of rose wilt.

\subsubsection{Preparation of Trichoderma viride and Bacillus subtilis inocula:}

The propagules (colony forming unit, CFU) suspensions of either $T$. viride or $B$. subtilis were prepared in sterile distilled water from 7 days-old-cultures on PDA (Rojo et al., 2007) or NGA (Sallam et al., 1978). The fungal or bacterial inoculum was harvested by flooding the culture with sterile distilled water and then rubbing the culture surface with sterile glass rod. The fungal or bacterial propagule concentrations (in each suspension) were determined by counting, using a hemocytometer slide, and then were adjusted at $6 \times 10^{5}$ spores $/ \mathrm{ml}$ for the fungus and $1 \times 10^{8} \mathrm{CFU} / \mathrm{ml}$ for bacteria. A mixture of milted soybean and talc powder $(1: 1 \mathrm{w} / \mathrm{w})$ was used as a carrier mixture for antagonistic organism propagules. A carrier mixture was added at the rate of $1: 1 \mathrm{w} / \mathrm{v}$ to fungal and bacterial suspensions and mixed to even distribution of antagonistic agent prop gules(Abd EL-Khair and ElMougy, 2003).

\subsubsection{Evaluation of antagonistic activity of bioagents in pot experiment:}

Antagonistic activity of both $T$. viride and B. subtilis against V.dahliaa (isolates No 1 and 2); the rose wilt inducing pathogen, was evaluated in pots under the artificial infestation conditions. First, soil was infested with isolates of pathogenic fungus separately in different pots and the pots were irrigated for 7 days before inoculation with the bio-control agent. Next, soil was inoculated with either $T$. viride or B. subtilis at $5 \mathrm{~g} / \mathrm{kg}$ soil, and then pots were watered for 7 days before planting. Three of rose cuttings were sown, at 15 January, in each pot and four pots were used as a replicate for each treatment as well as the control (untreated pots). Pots were kept under greenhouse conditions till the end of the experiment. Disease incidence and disease severity were recorded 60 days after planting.

\section{Statistical analysis:}

Data of all experiments were analyzed by analysis of variance (ANOVA) using the General Linear Models procedure of CoStat. Significance between means was tested by " $F$ " test and the value of LSD $(\mathrm{p}=0.05)$ was calculated (Snedecor and Cochran, 1982).

\section{Results and Discussion}

\section{Isolation and identification:}

Roses are subjected to attack by various disease pathogens which frequently induce severe losses in its plantations (Salamone et al., 2011). Wilt disease, caused by 
Verticillium dahliae, is considered as one of the most fungal diseases of rose. Verticillium wilt, caused by the soilborne fungus Verticillium dahliae, is an increasingly important disease of rose in the different parts of the world. The pathogen has a broad host range of more than 400 plant species, and can survive extremely long periods of time in the soil as microsclerotia. Nine isolates of a fungus identified as Verticillium dahliae, designated as $\mathrm{VD}_{1}-\mathrm{VD}_{9}$, were isolated from 1 and 2-years old rose plants exhibiting wilt symptoms, collected from the Experimental Greenhouse of Horticulture Department, Faculty of Agriculture, Minia University, and from commercial nurseries in Abo-Qurqascounty, Minia governorate during summer, 2012.

\section{Pathogenicity test:}

The effect of soil infestation with the fungal isolates obtained from naturally wilted rose plants on the incidence of rose wilt is shown in Table (2). The results show that all isolateswere able to induce wilt associated with different degrees of vascular discoloration on rose plants through 60 - 90 days after planting.

Table 2. Locality, disease incidence and disease severity of $V$. dahliae isolates causing wilt of rose

\begin{tabular}{|l|c|c|c|}
\hline \multicolumn{1}{|c|}{ Isolate } & Locality of sample & \%Disease incidence & \%Disease severity \\
\hline \hline VD $_{1}$ & Minia & 100.0 & 78.6 \\
VD $_{2}$ & Minia & 100.0 & 70.5 \\
VD $_{3}$ & Minia & 100.0 & 63.2 \\
VD $_{4}$ & Minia & 50.0 & 12.8 \\
VD $_{5}$ & Minia & 75.0 & 50.0 \\
VD $_{6}$ & Abo Qurqas & 41.7 & 10.1 \\
VD $_{7}$ & Abo Qurqas & 58.3 & 23.8 \\
VD $_{8}$ & Abo Qurqas & 91.7 & 43.5 \\
VD 9 & Abo Qurqas & 58.7 & 15.5 \\
LSD 5\% & - & 2.3 & 13.4 \\
\hline
\end{tabular}

The maximum percentages $(100 \%)$ of wilted plants occurred with isolates $\mathrm{VD}_{1}, \mathrm{VD}_{2}$ and $\mathrm{VD}_{3}$ isolated from Minia, followed by isolate $\mathrm{VD}_{8}$, isolated from Abo Qurqas county (caused $91.7 \%$ DI). The percentages of disease incidence ranged between 41.7 and 75.0 were induced by other isolates. The lowest percentage of infection (41.7) was caused by isolate $\mathrm{VD}_{6}$, isolated from Abo Qurqas wilted rose plants. The present study also revealed that isolates $\mathrm{VD}_{1}$ and $\mathrm{VD}_{2}$ were the most virulent isolates causing, 78.6 and $70.5 \%$, disease severity, respectively. Whereas, isolates $\mathrm{VD}_{9}, \mathrm{VD}_{4}$, $\mathrm{VD}_{6}$ and $\mathrm{VD}_{7}$ induced the lowest disease severity ranged between $10.1-23.8 \%$, 
without any significant values. The disease severity values ranged $23.8-63.2 \%$ were due to infection by the other isolates.

\section{3-Laboratory experiment:}

3.1. Effect of fungicides on the mycelial growth:

The effect of Rizolex-T 50\% WP and Topsin-M 70\% WP on the mycelial linear growth of Verticillium dahliae, the causal of rose wilt, was tested in the laboratory. Data presented in Table (3) clearly show thatall concentrations of Rizolex-T and Topsin-M decreased the linear growth of the four tested isolates. The fungitoxic effect was increased with increasing the fungicide concentration up to $400 \mathrm{ppm}$; the level that caused complete inhibition. According to the least rates that caused complete inhibition, the formers could be arranged descendingly as follows: TopsinM (200-400 ppm), and for Rizolex- T(400 ppm). The percentages of mycelial inhibition at $200 \mathrm{ppm}$ (the recommended dose) were ranged between $46.4-62.6$ for Risolex and $77.8-100 \%$ for Topsin. In general, Topsin showed better control against the isolates of $V$. dahliae. These results agree with those obtained by several investigators, Zahra (1990) and Ragab et al. (1999). Crowe and Parks (2000) reported that the effective dosage to reduce $V$. dahliaee growth by 50 percent ranged from 0.001 to $0.261 \mathrm{~g}$ a.i. /1 water of Quadris (active ingredient: azoxystrobin), Benlate (a.i.: benomyl), Vanguard (a.i.: cyprodinil), and Folicur (a.i.: tebuconazole). Ragabet al. (1999) reported that Rizolex -T and Topsin-M70 at 400 and 600 ppm, respectively, completely inhibited the growth of $F$. solani and Rhizoctonia solani, the causal pathogens of pea root-rot disease. Also, $R$. solani was more sensitive to Rizolex-T than Topsin-M, while an opposite trend was observed in the growth of $F$. oxysporum or F. solani (Abdel-Kader, 1997 and Ragabet al.1999).

\section{3-2- Effect of two nutrient compounds on fungal growth:}

Two commercial nutrient compounds (Phos-Root- $X$ and Formula $X-1$ ) were used to study their effects on the linear growth of the most pathogenic isolates of rose wilt pathogen under laboratory conditions.Data presented in Table (4) show that Phosroot $\mathrm{X}$ showed stimulation effect on the growth of the four tested isolates at the rate 1.5 and $2.25 \mathrm{ml} / \mathrm{l}$. The highest increase was obtained at $2.25 \mathrm{ml} / 1$ for isolates $\mathrm{VD}_{3}$ and $\mathrm{VD}_{8}$. On the other hand, the compound Formula X-1 stimulated the growth of all tested isolates of $V$. dahliae at the low concentrations ( 0.5 and $1.0 \mathrm{ml} / \mathrm{l}$ ) whereas at the highest concentration $(3 \mathrm{ml} / \mathrm{l})$ the growth was decreased. 
Table 3. Toxicity of different concentrations of fungicides againstfour isolates of the causal organism of rose wilt on PDA medium

\begin{tabular}{|c|c|c|c|c|c|c|}
\hline \multirow{2}{*}{ Fungieides } & \multirow{2}{*}{ Cone. } & \multicolumn{5}{|c|}{ Fungal linear growth inhibition $(\%)$ for isolates } \\
\hline & & $\mathrm{VD}_{1}$ & $\mathrm{VD}_{2}$ & $\mathrm{VD}_{3}$ & $\mathrm{VD}_{8}$ & Mean \\
\hline & 0.0 & 0.0 & 0.0 & 0.0 & 0.0 & 0.0 \\
\hline \multirow{4}{*}{$\begin{array}{l}\text { Rizolex-T } \\
\text { (ppm) }\end{array}$} & 50 & 8.1 & 14.8 & 15.9 & 26.3 & 16.3 \\
\hline & 100 & 31.1 & 33.7 & 33.7 & 43.7 & 35.6 \\
\hline & 200 & 59.7 & 62.6 & 55.9 & 46.4 & 56.2 \\
\hline & 400 & 100 & 100 & 100 & 100 & 100 \\
\hline \multicolumn{2}{|l|}{ Mean } & 39.8 & 42.2 & 41.1 & 43.3 & 41.6 \\
\hline & 0.0 & 0.0 & 0.0 & 0.0 & 0.0 & 0.0 \\
\hline & 50 & 11.1 & 23.7 & 24.8 & 36.3 & 24.0 \\
\hline 10p5T1 & 100 & 38.9 & 46.7 & 50.0 & 67.8 & 50.9 \\
\hline (ppmint & 200 & 100.0 & 77.8 & 81.1 & 80.3 & 84.8 \\
\hline & 400 & 100.0 & 100.0 & 100.0 & 100.0 & 100.0 \\
\hline \multicolumn{2}{|l|}{ Mean } & 44.9 & 45.9 & 46.2 & 50.1 & 46.8 \\
\hline \multicolumn{2}{|c|}{ Mean } & 42.3 & 44.1 & 43.7 & 46.7 & 44.2 \\
\hline \multicolumn{7}{|c|}{$\begin{array}{l}\text { L.S.D. } 5 \% \text { for: Fungicides }(A)=0.26 \text {, Conc. }(C)=0.41 \text {, Isolates }(I)=0.08 \text {, } \\
A C I=1.17\end{array}$} \\
\hline
\end{tabular}

Table 4. Effect of two nutrient compounds on the mycelial linear growth of the most pathogenic isolates of Verticillium dahliae the causal of rose wilt

\begin{tabular}{|c|c|c|c|c|c|c|}
\hline \multirow{2}{*}{ Compound } & \multirow{2}{*}{ Cone. } & \multicolumn{5}{|c|}{ Fungal linear growth $(\mathrm{mm})$ for isolates } \\
\hline & & $\mathrm{VD}_{1}$ & $\mathrm{VD}_{2}$ & $\mathrm{VD}_{3}$ & $\mathrm{VD}_{8}$ & Mean \\
\hline & 0.0 & 77.7 & 74.3 & 62.0 & 66.0 & 70.0 \\
\hline Phos-root X, & 0.75 & 79.0 & 72.7 & 76.3 & 66.7 & 73.7 \\
\hline concentration & 1.5 & 73.3 & 85.7 & 71.7 & 83.0 & 78.4 \\
\hline \multirow[t]{2}{*}{$\mathrm{ml} / \mathrm{l}(\mathrm{v} / \mathrm{v})$} & 2.25 & 88.0 & 90.0 & 89.3 & 90.0 & 89.3 \\
\hline & 3.0 & 71.7 & 47.7 & 53.0 & 52.3 & 56.2 \\
\hline \multicolumn{2}{|l|}{ Mean } & 77.9 & 74.1 & 70.5 & 71.6 & 73.5 \\
\hline & 0.0 & 81.3 & 70.3 & 67.7 & 75.7 & 73.8 \\
\hline Formula X-1, & 0.50 & 89.7 & 85.0 & 81.3 & 90.0 & 86.5 \\
\hline concentration & 1.0 & 90.0 & 88.7 & 84.3 & 87.3 & 87.6 \\
\hline \multirow[t]{2}{*}{$\mathrm{ml} / \mathrm{l}(\mathrm{v} / \mathrm{v})$} & 1.5 & 73.3 & 65.3 & 61.3 & 68.0 & 67.0 \\
\hline & 2.0 & 64.0 & 56.7 & 48.0 & 57.7 & 56.6 \\
\hline \multicolumn{2}{|l|}{ Mean } & 83.7 & 74.2 & 68.5 & 75.7 & 74.3 \\
\hline \multicolumn{2}{|l|}{ Mean } & 80.8 & 74.2 & 69.5 & 73.7 & 73.9 \\
\hline
\end{tabular}


$=0.7$

3.3. Effect of the antagonists on the growth of Verticillium wilt isolates in vitro:

Data presented in Table (5)show that both bioagents, i.e.T. viride and B. subtilis were able to inhibit the mycelial growth of all isolates tested, but they varied in their ability to antagonistic effect. In general, B. subtilis was more effective in inhibiting the growth of Verticillium isolates than T. viride where it gave 64.8 and $84.9 \%$ inhibition while $T$. viride gave $50-79.3 \%$ inhibition. Data show, also, that isolates $\mathrm{VD}_{3}$ and $\mathrm{VD}_{1}$ were more sensitive to $T$. viride, whereas isolates $\mathrm{VD}_{1}$ and $\mathrm{VD}_{8}$ were more sensitive to $B$. subtilis. Isolates $\mathrm{VD}_{2}$ and $\mathrm{VD}_{3}$ were the least affected ones by either $T$. viride or $B$. subtilis, respectively.

Table 5. Effect of $T$. viride and $B$. subtilison the growth of $V$. dahliae isolates, in vitro

\begin{tabular}{|l|c|c|c|c|c|}
\hline \multicolumn{1}{|c|}{ Isolate No. } & \multicolumn{3}{|c|}{ Linear growth (mm) } & \multicolumn{2}{c|}{ \% inhibition } \\
\hline \hline & T. viride & B. subtilis & Control & T. viride & B. subtilis \\
\hline \hline $\mathrm{VD}_{1}$ & 26.7 & 12.7 & 90.0 & 70.3 & 85.9 \\
\hline \hline $\mathrm{VD}_{2}$ & 38.0 & 16.7 & 90.0 & 57.8 & 81.4 \\
\hline $\mathrm{VD}_{3}$ & 18.7 & 31.7 & 90.0 & 79.3 & 64.8 \\
\hline \hline $\mathrm{VD}_{8}$ & 45.3 & 13.7 & 90.0 & 50.0 & 84.9 \\
\hline \hline Mean & 32.2 & 18.7 & 90.0 & 64.4 & 79.3 \\
\hline \hline \multicolumn{2}{|l}{ L.S.D. 5\% for: Isolates (A) } & $=4.8$, Bioagents (B) $=6.9, \mathrm{~A} \times \mathrm{B}=9.7$ \\
\hline
\end{tabular}

4-Greenhouse experiments:

4.1. Efficiency of the tested fungicideson infection in pot experiment:

Data in Tables (6 and 7) point out to the following:

In general, Rizolex-T, however, preceded Topsin-M70 in their efficiency. The percentages of disease reduction ranged between $28.5-100 \%$, and the percentages of DS\% ranged between $60.33-100 \%$ when Rizolex-T was applied, in the first season, whereas, the reduction in DI\% ranged between $8.3-91 \%$, and DS\% ranged between 63.3 and $98.1 \%$ when Topsin-70 was applied. The average of disease reduction percentages and disease severity for $\mathrm{VD}_{1}$ and $\mathrm{VD}_{2}$ was more when Rizolex-T was applied, than using Topsin M-70. The mean value of reduction of DI and DS\% in case of isolate $\mathrm{VD}_{8}, 75.1 \mathrm{DI} \%$ and $84.0 \% \mathrm{DS} \%$, was higher with Topsin M-70 than that recorded with Rizolex-T. The isolate $\mathrm{VD}_{2}$ was the most affected one when Rizolex-T was tested (causing reduction in DI\% 77.8 and $74.5 \%$ and DS\% 89.6 and $85.5 \%$, in the two seasons, respectively).

The effect of Rizolex on wilt on rose incidence and severity was better than Topsin M-70. The results in 2014 showed the same trend as the first season.Similar results

Egypt. J. Phytopathol., Vol. 44, No. 2(2016) 
concerning the effect of Rizolex-T and Topsin-M at different concentrations were also reported byRagabet al. (1999) and Abdel-Kader (1997 and 2004). Crowe and Parks (2000)found that Quadris, Benlate, Vanguard and Folicur and several additional materials, i.e. Actigard, a low rate of Vapam fumigant and Acid Replacement Solution (ARS), stopped wilt symptoms in peppermint plants when materials were drenched onto potted peppermint plants sown in $V$. dahliae-infested soil. Woodward and Wheeler (2011) reported that Vapam (7-20 gallons per acre) has proved to be inefficient in reducing Verticillium wilt severity, or increasing yields. They reported also that Topsin-M is labeled for use against foliar and boll rot diseases, but not Verticillium wilt.

Table 6. Effect of Rizolex-T and Topsin M-70 treatment on rose wilt diseaseincidence and severity during 2013 season

\begin{tabular}{|c|c|c|c|c|c|c|c|c|c|}
\hline \multirow{3}{*}{ Isolate } & \multirow{3}{*}{$\begin{array}{c}\text { Conc. } \\
\mathrm{ml} / 1\end{array}$} & \multicolumn{8}{|c|}{ Disease assessment, $\%$} \\
\hline & & \multicolumn{4}{|c|}{ Rizolex-T } & \multicolumn{4}{|c|}{ Topsin-70 } \\
\hline & & $\begin{array}{c}\text { D.I., } \\
\%\end{array}$ & $\begin{array}{l}\%, \mathrm{Re}- \\
\text { duction }\end{array}$ & $\mathrm{DS}, \%$ & $\begin{array}{l}\%, \mathrm{Re}- \\
\text { duction }\end{array}$ & D.I., \% & $\begin{array}{l}\%, \mathrm{Re}- \\
\text { duction }\end{array}$ & $\mathrm{DS}, \%$ & $\begin{array}{l}\%, \mathrm{Re}- \\
\text { duction }\end{array}$ \\
\hline \multirow[t]{5}{*}{$\mathrm{VD}_{1}$} & 0.0 & 75.0 & -- & 53.6 & -- & 91.0 & -- & 71.4 & -- \\
\hline & 1.5 & 58.3 & 22.3 & 21.3 & 60.3 & 50.0 & 45.1 & 26.2 & 63.3 \\
\hline & 3.0 & 33.3 & 55.6 & 10.7 & 80.0 & 41.7 & 54.2 & 19.0 & 73.4 \\
\hline & 4.5 & 25.0 & 66.7 & 6.0 & 88.8 & 25.0 & 75.5 & 8.3 & 88.4 \\
\hline & Mean & 47.9 & 48.2 & 22.9 & 76.4 & 51.9 & 57.3 & 31.2 & 75.0 \\
\hline \multirow[t]{5}{*}{$\mathrm{VD}_{2}$} & 0.0 & 75 & -- & 53.6 & -- & 91.7 & -- & 64.3 & -- \\
\hline & 1.5 & 33.3 & 55.6 & 10.7 & 80.3 & 50.0 & 45.5 & 22.6 & 64.9 \\
\hline & 3.0 & 16.7 & 77.7 & 6.0 & 88.8 & 50.0 & 45.5 & 17.9 & 72.2 \\
\hline & 4.5 & 0.0 & 100.0 & 0.0 & 100.0 & 16.7 & 81.8 & 7.1 & 89.0 \\
\hline & Mean & 31.3 & 77.8 & 53.6 & 89.6 & 52.1 & 57.6 & 27.9 & 75.4 \\
\hline \multirow[t]{5}{*}{$\mathrm{VD}_{8}$} & 0.0 & 58.3 & -- & 46.4 & -- & 83.3 & -- & 64.3 & -- \\
\hline & 1.5 & 41.7 & 28.5 & 14.3 & 69.2 & 50.0 & 40.0 & 15.5 & 76.0 \\
\hline & 3.0 & 16.7 & 71.4 & 4.8 & 89.7 & 41.7 & 49.9 & 14.3 & 77.8 \\
\hline & 4.5 & 16.7 & 71.4 & 3.6 & 92.2 & 8.3 & 90.0 & 1.2 & 98.1 \\
\hline & Mean & 29.2 & 75.1 & 17.2 & 83.7 & 45.8 & 60.0 & 23.8 & 84.0 \\
\hline \multicolumn{10}{|c|}{ LSD 5\% For: DI, $\% \quad$ DS, $\%$} \\
\hline \multicolumn{3}{|c|}{ Isolates (A) } & $=4.8$ & & $=4.5$ & & & & \\
\hline \multicolumn{3}{|c|}{ Fungicides (B) } & $=0.6$ & & $=0.3$ & & & & \\
\hline \multicolumn{3}{|c|}{ Concentrat. (C) } & $=0.2$ & & $=0.3$ & & & & \\
\hline \multicolumn{2}{|c|}{ A.B.C. } & & $=0.4$ & & $=0.2$ & & & & \\
\hline
\end{tabular}

1. Each reading is average of 4 replicates, each containing 3 plants.

Egypt. J. Phytopathol., Vol. 44, No. 2(2016) 
Table 7. Effect of Rizolex-T and Topsin M-70 treatment on rose wilt disease incidence and severity during 2014 season

\begin{tabular}{|c|c|c|c|c|c|c|c|c|c|}
\hline \multirow[b]{3}{*}{ Isolate } & \multirow[b]{3}{*}{$\begin{array}{c}\text { Conc. } \\
\mathrm{ml} / \mathrm{l}\end{array}$} & \multicolumn{8}{|c|}{ Disease reduction, $\%$} \\
\hline & & \multicolumn{4}{|c|}{ Rizolex- T } & \multicolumn{4}{|c|}{ Topsin-70 } \\
\hline & & $\begin{array}{c}\text { D.I., } \\
\%\end{array}$ & $\begin{array}{c}\% \text { Re- } \\
\text { duction }\end{array}$ & $\mathrm{DS}, \%$ & $\begin{array}{l}\% \text { Re- } \\
\text { duction }\end{array}$ & $\begin{array}{c}\text { D.I., } \\
\%\end{array}$ & $\begin{array}{c}\% \text { Re- } \\
\text { duction }\end{array}$ & $\mathrm{DS}, \%$ & $\begin{array}{l}\% \mathrm{Re}- \\
\text { duction }\end{array}$ \\
\hline \multirow{5}{*}{$\mathrm{DV}_{1}$} & 0.0 & 83.3 & -- & 61.9 & -- & 75.0 & \multirow{5}{*}{$\begin{array}{c}-- \\
0.0 \\
33.3 \\
88.9 \\
40.7\end{array}$} & 54.8 & -- \\
\hline & 1.5 & 75.0 & 10.0 & 25.0 & 59.6 & 75.0 & & 17.9 & 67.3 \\
\hline & 3.0 & 33.3 & 60.0 & 6.0 & 90.3 & 50.0 & & 13.1 & 76.1 \\
\hline & 4.5 & 25.0 & 70.0 & 3.6 & 94.2 & 8.3 & & 1.2 & 97.8 \\
\hline & Mean & 48.4 & 46.7 & 24.1 & 81.4 & 52.1 & & 21.7 & 80.4 \\
\hline \multirow{5}{*}{$\mathrm{DV}_{2}$} & 0.0 & 75.0 & -- & 52.4 & -- & 91.7 & \multirow{5}{*}{$\begin{array}{c}-- \\
27.3 \\
54.5 \\
72.7551 .5\end{array}$} & 59.5 & -- \\
\hline & 1.5 & 25.0 & 66.7 & 11.9 & 77.3 & 66.7 & & 17.9 & 69.9 \\
\hline & 3.0 & 25.0 & 66.7 & 7.3 & 86.1 & 41.7 & & 14.3 & 76.0 \\
\hline & 4.5 & 8.3 & 90.0 & 3.6 & 93.1 & 25.0 & & 7.1 & 88.1 \\
\hline & Mean & 33.3 & 74.5 & 18.8 & 85.5 & 41.3 & & 24.7 & 78.0 \\
\hline \multirow{5}{*}{$\mathrm{VD}_{8}$} & 0.0 & 75.0 & -- & 53.6 & -- & 75.0 & \multirow{5}{*}{$\begin{array}{c}-- \\
66.7 \\
55.6 \\
100.0 \\
74.1\end{array}$} & 47.6 & -- \\
\hline & 1.5 & 58.3 & 22.3 & 16.7 & 68.8 & 25.0 & & 10.7 & 77.5 \\
\hline & 3.0 & 41.7 & 44.4 & 17.9 & 66.6 & 33.3 & & 11.9 & 75.0 \\
\hline & 4.5 & 16.7 & 77.7 & 6.0 & 88.8 & 0.0 & & 0.0 & 100.0 \\
\hline & Mean & 47.9 & 48.1 & 23.5 & 74.4 & 33.3 & & 17.5 & 84.2 \\
\hline \multicolumn{3}{|c|}{ LSD 5\% for: } & DI, $\%$ & & \multicolumn{5}{|l|}{$\mathrm{DS}, \%$} \\
\hline \multicolumn{3}{|c|}{ Isolates (A) } & $=5.1$ & & \multicolumn{5}{|l|}{$=0.11$} \\
\hline \multicolumn{3}{|c|}{ Fungicides (B) } & $=1.3$ & & \multicolumn{5}{|l|}{$=0.6$} \\
\hline \multicolumn{3}{|c|}{ Concentrations (C) } & $=0.2$ & & \multicolumn{5}{|l|}{$=0.4$} \\
\hline \multicolumn{3}{|c|}{ A.B.C. } & $=0.8$ & & \multicolumn{5}{|l|}{$=0.4$} \\
\hline
\end{tabular}

1. Each reading is average of 4 replicates, each containing 3 plants.

Verticillium wilt development:

Initial infections occur early in the growing season, following the germination of microsclerotia. The fungus infects through the roots, invades the vascular system resulting in a systemic infection. A number of compounds that do not have direct antimicrobial activity increase resistance or at least decrease symptoms in some host-pathogen interaction (Hammerschmidt and Smith, 1997). The fertilizers not only having direct physiological effects on the plant growth but also affect the

Egypt. J. Phytopathol., Vol. 44, No. 2(2016) 
physiological activities of the pathogens (Curl and Rodriguez-Kabana, 1973). To clarify the role of $\mathrm{Zn}, \mathrm{Fe}, \mathrm{Cu}$, and $\mathrm{Mn}$ on disease incidence, many investigations (Ziadiet al., 2001; Cakmak and Marschner, 1992 and Ragabet al., 2009) were carried out showing their role in the oxidative enzymes activities to find out an explication of the effect of some nutritive micro-elements in plant resistance. The role of amino acids in plant disease control may be due to the correlation between these acids and plant health. In this respect, Bush (1993) reported that amino acids may be used for the production of new cell biomass and to produce energy. He explained that domination of keto amino acids through the tri-carboxylic acid cycle plays an important role in plant resistance against the pathogens. Since several comprehensive review articles have previously discussed recent progresses in the antimicrobial peptide research (Bockus et al., 2013 and Singh et al., 2013).

\subsection{Effect of two nutrient compounds on rose-wilt incidence.}

The lowestincidence and severity ofthe disease was recorded with the highest level of the compound ( 3 or $2 \mathrm{ml} / \mathrm{l}$ for Phos-Root $\mathrm{X}$ and Formula-X, respectively) with any of the tested isolates. Data in Table (8) clear that DI \% and DS\% were higher in the first season in control treatments and when the lowest level of the compounds was tested comparing with the second season. Formula-X reduced the percentages of both DI \% and DS\% more than Phos-Root X, especially in the second season. Several methods were suggested for controlling soil-borne fungi, i.e. improving the sanitation procedures, agricultural practices, chemical control, biological control. Several factors including variety selection, plant density, pathogen aggressiveness, inoculum density (micro-sclerotia per gram of soil) and environmental conditions which influence

\subsection{Effect of two bioagents on controlling Verticillium rose wilt under greenhouse conditions:}

Soil treatment with biocontrol agents, i.e. T.viride and B. subtilis at concentrations $5 \mathrm{~g}$ of $10^{5}$ spores $/ \mathrm{ml}$ and $10^{6} \mathrm{CFU} / \mathrm{ml} / \mathrm{kg}$ soil, respectively, on wilt incidence was studied during two successive seasons 2013 and 2014 under greenhouse conditions. Data in Table (9) indicate that addition of the two bio-agents, each alone to the soil one week before planting significantly decreased the percentages of infected rose plants grown in infested soil with any tested isolate of $V$. dahliae. Disease incidence percentage was reduced by $44.4-75.0 \%$ when soil was infested with $T$, viride, while it was 77.7- 87.6 when B. subtilis was used. Also, disease severity percentages were reduced by $67.5-81.4$ when $T$. viride was applied and by $83.9-89.0$ when $B$. subtilis was usedto antagonist $V$. dahliae isolates. In general, $B$. subtilis affected $V$. dahliae more than $T$. viride. The highest reduction percentages being $87.6 \%$ for DI and $89.0 \%$ for DS were found when the bacteria were applied against isolateVD $\mathrm{D}_{8}$. 
Table 8. Effect of treating rose cuttings with two nutrients on Verticillium wiltincidence and severity during seasons 2013 and 2014

\begin{tabular}{|c|c|c|c|c|c|c|}
\hline \multirow{3}{*}{$\begin{array}{l}\text { Isolate } \\
\text { No. }\end{array}$} & \multirow{3}{*}{ Chemicals } & \multirow{3}{*}{$\begin{array}{l}\text { Conc. } \\
\mathrm{ml} / \mathrm{kg} \text { soil }\end{array}$} & \multicolumn{4}{|c|}{$\begin{array}{c}\text { Incidence and severity of the disease }(\%) \\
\text { during }\end{array}$} \\
\hline & & & \multicolumn{2}{|c|}{2013} & \multicolumn{2}{|c|}{2014} \\
\hline & & & DI & DS & DI & DS \\
\hline \multirow[t]{4}{*}{$\mathrm{VD}_{1}$} & \multirow[t]{12}{*}{ Phos-Root X } & $0.75 \mathrm{ml} / \mathrm{L}$ & 75.0 & 17.9 & 58.3 & 33.3 \\
\hline & & $1.5 \mathrm{ml} / \mathrm{L}$ & 58.3 & 15.4 & 50.0 & 26.2 \\
\hline & & $3.0 \mathrm{ml} / \mathrm{L}$ & 50.0 & 10.7 & 41.7 & 80.3 \\
\hline & & Control $^{(*)}$ & 83.3 & 59.5 & 75.0 & 52.4 \\
\hline \multirow[t]{4}{*}{$\mathrm{VD}_{2}$} & & $0.75 \mathrm{ml} / \mathrm{L}$ & 41.7 & 17.9 & 75.0 & 60.7 \\
\hline & & $1.5 \mathrm{ml} / \mathrm{L}$ & 50.0 & 20.2 & 33.3 & 15.5 \\
\hline & & $3.0 \mathrm{ml} / \mathrm{L}$ & 41.7 & 14.3 & 25.0 & 11.9 \\
\hline & & Control & 75.0 & 51.2 & 83.3 & 75.0 \\
\hline \multirow[t]{4}{*}{$\mathrm{VD}_{3}$} & & $0.75 \mathrm{ml} / \mathrm{L}$ & 58.3 & 19.0 & 75.0 & 35.7 \\
\hline & & $1.5 \mathrm{ml} / \mathrm{L}$ & 58.3 & 20.2 & 50.0 & 15.5 \\
\hline & & $3.0 \mathrm{ml} / \mathrm{L}$ & 41.7 & 8.3 & 25.0 & 8,3 \\
\hline & & Control & 75.0 & 50.0 & 58.3 & 64.7 \\
\hline \multirow[t]{4}{*}{$\mathrm{VD}_{1}$} & Formula X-1 & $0.5 \mathrm{ml} / \mathrm{L}$ & 58.3 & 11.9 & 83.3 & 53.6 \\
\hline & & $1.0 \mathrm{ml} / \mathrm{L}$ & 58.3 & 23.8 & 58.3 & 33.3 \\
\hline & & $1.5 \mathrm{ml} / \mathrm{L}$ & 58.3 & 20.2 & 33.3 & 8.3 \\
\hline & & Control & 75.0 & 40.5 & 75.0 & 57.1 \\
\hline \multirow[t]{4}{*}{$\mathrm{VD}_{2}$} & & $0.5 \mathrm{ml} / \mathrm{L}$ & 50.0 & 15.5 & 66.7 & 50.0 \\
\hline & & $1.0 \mathrm{ml} / \mathrm{L}$ & 33.3 & 8.3 & 41.7 & 22.6 \\
\hline & & $1.5 \mathrm{ml} / \mathrm{L}$ & 16.7 & 6.0 & 16.7 & 7.1 \\
\hline & & Control & 75.0 & 42.6 & 91.7 & 67.9 \\
\hline \multirow[t]{4}{*}{$\mathrm{VD}_{8}$} & & $0.5 \mathrm{ml} / \mathrm{L}$ & 66.7 & 16.7 & 58.3 & 25.0 \\
\hline & & $1.0 \mathrm{ml} / \mathrm{L}$ & 50.0 & 9.5 & 58.3 & 16.7 \\
\hline & & $1.5 \mathrm{ml} / \mathrm{L}$ & 50.0 & 16.7 & 25.0 & 4.8 \\
\hline & & Control & 75.0 & 40.5 & 91.7 & 63.1 \\
\hline \multirow[t]{4}{*}{ LSD:5\% } & \multirow{4}{*}{\multicolumn{2}{|c|}{$\begin{array}{l}\text { For: Isolates (A) } \\
\text { Compounds (B) } \\
\text { Concentrations (C) } \\
\text { AxBxC }\end{array}$}} & $=4.2$ & $=0.2$ & $=$ n.s. & $=0.2$ \\
\hline & & & $=0.5$ & $=0.7$ & $=1.4$ & $=0.3$ \\
\hline & & & $=0.3$ & $=0.4$ & $=0.2$ & $=0.3$ \\
\hline & & & $=0.6$ & $=1.7$ & $=0.4$ & $=0.5$ \\
\hline
\end{tabular}

${ }^{(*)}$ control consisted of plants treatedwith water instead of nutrient substance.

Isolate $\mathrm{VD}_{8}$ was strongly affected (the average of DI reduction percentages was 81.3) when compared with either isolate $\mathrm{VD}_{1}(70.0 \%)$ or isolate $\mathrm{VD}_{2}(61.5 \%)$ by the application of the bioagent organisms. The introducing bioagent and fungicide as well into the soil is facing undesirable conditions. Therefore, they must withstand these conditions in order to achieve the proposed approach. Many investigators

Egypt. J. Phytopathol., Vol. 44, No. 2(2016) 
suggested such phenomena. Papavizas (1982)reported that the high population density of Trichoderma harzianum, introduced through soil treatment technique, enables the bioagent to adapt itself against environmental conditions and resulting in dominance of high population of the fungus. Moreover, Cook and Baker (1983) indicated that any colonizing microorganism given the advantage of being the first to colonize the root, has the potential to promote the nutrient supply of the pathogens. In 1981, Abd El-Moity stated that activity of T. harzianum acts through different mechanisms, i.e., production of gliotoxin, mycoparasitism, growing very fast and acts as a barrier between susceptible plant tissues and virulent pathogens. Many species of the genera Bacillus and Trichoderma are known to be potent producers of many antibiotics against soil-borne-pathogens (Ahmed et al., 2003 and Han et al., 2005).

Table 9. The effect of $T$. viride and $B$. subtilis treatments on incidence of rose wilt under greenhouse condition

\begin{tabular}{|c|c|c|c|c|c|c|c|c|c|}
\hline \multirow{3}{*}{$\begin{array}{l}\text { Isolate } \\
\text { No. }\end{array}$} & \multirow{3}{*}{ Bioagent } & \multicolumn{8}{|c|}{$\begin{array}{c}\text { Incidence and severity of the disease }(\%) \\
\text { during }\end{array}$} \\
\hline & & \multicolumn{4}{|c|}{2013} & \multicolumn{4}{|c|}{2014} \\
\hline & & D.I. & $\begin{array}{c}\% \\
\text { Red. }\end{array}$ & D.S. & $\begin{array}{c}\% \\
\text { Red. }\end{array}$ & D.I. & $\begin{array}{c}\% \\
\text { Red. }\end{array}$ & D.S. & $\begin{array}{c}\% \\
\text { Red. }\end{array}$ \\
\hline \multirow{5}{*}{ DV1 } & T. viride & 33.3 & 60.0 & 9.5 & 81.4 & 25.0 & 72.7 & 9.5 & 84.03 \\
\hline & B. subtilis & 16.7 & 80.0 & 6.0 & 88.3 & 33.3 & 63.7 & 10.7 & 82.01 \\
\hline & Control & 83.3 & -- & 51.2 & -- & 91.7 & -- & 59.5 & -- \\
\hline & Mean & 44.4 & 70.0 & 22.2 & 85.0 & 50.0 & 68.2 & 26.5 & 83.02 \\
\hline & T. viride & 33.3 & 44.4 & 14.3 & 67.5 & 25.0 & 62.3 & 11.9 & 64.3 \\
\hline \multirow[t]{4}{*}{ DV2 } & B. subtilis & 16.7 & 77.7 & 7.1 & 83.9 & 8.3 & 87.5 & 3.6 & 89.2 \\
\hline & Control & $75 . .0$ & -- & 44.0 & -- & 66.3 & -- & 33.3 & -- \\
\hline & Mean & 41.7 & 61.5 & 21.8 & 75.7 & 33.2 & 74.9 & 16.8 & 76.8 \\
\hline & T. viride & 16.7 & 75.0 & 8.3 & 79.5 & 41.7 & 49.9 & 15.5 & 75.2 \\
\hline \multirow[t]{3}{*}{ DV8 } & B. subtilis & 8.3 & 87.6 & 4.5 & 89.0 & 16.7 & 79.9 & 8.3 & 86.6 \\
\hline & Control & 66.7 & -- & 40.5 & -- & 83.3 & -- & 61.9 & -- \\
\hline & Mean & 30.6 & 81.3 & 17.7 & 84.3 & 47.2 & 64.9 & 28.5 & 80.9 \\
\hline \multicolumn{2}{|c|}{$\begin{array}{l}\text { LSD 5\% for: } \\
\text { Isolates (A) }\end{array}$} & & & & \multicolumn{2}{|c|}{$=0.3$} \\
\hline \multicolumn{2}{|c|}{ Bioagents (B) } & \multicolumn{2}{|c|}{$=0.2$} & \multicolumn{2}{|c|}{$=0.5$} & \multicolumn{2}{|c|}{$=0.3$} & \multicolumn{2}{|c|}{$=0.6$} \\
\hline \multicolumn{2}{|c|}{$\mathrm{A} \times \mathrm{B}$} & \multicolumn{2}{|c|}{$=0.1$} & \multicolumn{2}{|c|}{$=0.2$} & \multicolumn{2}{|c|}{$=0.7$} & \multicolumn{2}{|c|}{$=0.7$} \\
\hline
\end{tabular}

These suggestions may clarify the low disease incidence in the present study when B. subtilis or $T$. viride was introduced to the soil infested with $V$. daliae. Similar 
results were obtained when a Trichoderma preparation was mixed with soil artificially inoculated with $F$. oxysporum f.sp. chrysanthemi, the causal of chrysanthemum wilt (Locke et al., 1985).The results of this investigation are closely in agreement, also, with those obtained by Lacicowa and Pieta (1996)who found that dressing pea seeds with microbiological materials prepared from Trichoderma koningi and $T$. viride were most efficient in protecting pea from $R$. solani and Fusarium spp. in soil. Also, Sunick et al. (1997) recorded that Bacillus sp.gave a highly antagonistic effect against different soil-borne pathogenic fungi tested. Elad et al. (1983) and Seema and Devaki (2012) explained the phenomenon of mycoparasitism as a complex process, involving recognition of the host, attachment to the mycelium, coiling around the hyphae, partial degradation of the cell wall and penetration of the host mycelium. Scanning electron microscope clearly showed that the hyphae of Trichoderma sp. coil around the hyphae of Rhizoctonia solani (the host), attached to host mycelium by forming hooks and produced approssoria at the tips of short branches (Eladet al., 1983).

\section{R e f e r e n c es}

Abdel-Kader,M.M. 1997. Field application of Trichoderma harazianum as biocide for control bean root rot disease. Egypt. J. Phytopathol., 25(1-2): 19 - 25.

Abdel-Kader, M.M. El-Bahr, M.K. and El-Mougy,Nehal S. 2004. Pathogenic fungi and soil conditions causing root rot and wilt disease complex during acclimatization of tissue culture-derived banana plantlets. Egypt. J. Phytopathol., 32(1-2): 37-48.

Abd EL-Khair, H. and El-Mougy,Nehal S. 2003. Field biological approach under organic cultivation conditions for controlling garlic black mould diseaseinfection during storage. Egypt. J. Appl. Sci., 18(6): 50 - 69.

Abd El-Moity, T.H. 1981. Further studies on the biological control of white rot disease of onion. Ph. D. Thesis, Faculty of Agriculture, Minufiya University, $135 \mathrm{p}$.

Ahmed, A.S.;Ezziyyani, M.;Sachez, C.P. and Candela, M.R. 2003. Effects of chitin on biological control activity of Bacillus spp., and Trichoderma harzianumagainst root rot diseases of pepper (Capsicum annum) plants. Eur. J. Plant Pathol., 109:633-637.

Anonymous, 2012. Brief of Agricultural Statistics. Area, yield, and production for medical, aromatic, ornamental plants \& cutting flowers in old and new lands.

Egypt. J. Phytopathol., Vol. 44, No. 2(2016) 
Economic Affairs Sector, Ministry of Agriculture and Land Reclamation, Arab Republic of Egypt. pp:1-85.

Aushor, R.; Katan, J. and Ovadia, S.1975. An improved selective medium for the isolation Verticillium dahliae.Phytoparasitica,3(2): 133-137.

Barguil, B.M.; Viana, R.M.; Anjos, R.M. and Cardosa, J.E. 2009. First report of dry rot caused by Fusarium oxysporum on rose (Rosa spp.) in Brazil. Plant Dis.,93(7): 766.

Bejarano-Alcázar, J.; Blanco-López, M.A.;Melero-Vara, J.M. and Jiménez-Díaz, R.M. 1996. Etiology, importance, and distribution ofVerticillium of cotton in southern Spain. Plant Dis., 80:1233-1238.

Bell,D.K.; Wells, H.D. and Markham B.B. 1982. In vitro antagonism of Trichoderma species against six fungal plant pathogens. Phytopathology, 72:379-382.

Bockus, A.T.;McEwen, C.M. and Lokey, R.S.2013. Form and function in cyclic peptide natural products: a pharmacokinetic perspective. Current Top. Med. Chem.,13: 821-836.

Booth, C. 1971. The Genus Fusarium. Commonwealth mycological Institute. Kew, Surrey, England. pp:1-237.

Bush, D.R. 1993. Proton coupled sugar and amino acid transporters in plants. Ann. Rev. of Pl. Physiol. and Plant Biol., 44:513-542.

Cakmak, I. and Marschner, H. 1992. Magnesium deficiency and high light intensity enhance activities of superoxide dismutase, ascorbate peroxidase and glutathione reductase in bean leaves. Plant Physiol., 98:1222-1227.

Cook, R.I. and Baker, K.F. 1983. The Nature and Practice of Biological Control of Plant Pathogens. Amer.Phytopathol. Soc, St. Paul, MN, pp:1-539.

Crowe,F. and Parks, R. 2000. Fungicide screening for control of Verticillium wilt of peppermint. Oregon State Univ. www.oregonstate.edu. sites, files and publications. 10p.

Curl, E.A. and Rodriguez-Kabana, R. 1973. Soil fertility and root infecting fungi. Southern Cooperative. Series Bulletin, 183: 47-50.

Elad, Y.; Chet, I.; Boyle, P. and Henis, Y. 1983. Parasitism of Trichoderma spp. on Rhizoctoniasolani and Sclerotium rolfsii: scanning electron microscopy and fluorescence microscopy. Phytopathology, 73: 85-88.

Egypt. J. Phytopathol., Vol. 44, No. 2(2016) 
Ferreira, J.H.S.;Matthe, F.N. and Thomas, A.C.1991. Biological control of Eutypalataon grapevine by an antagonistic strain of Bacillus subtilis. Phytopathology, 81: 283-287.

Gilman, J.C. 1957. A manual of Soil Fungi, $2^{\text {nd }}$ ed. The Iowa State College Press.

Hammerschmidt, R. and Smith, J.B.1997. Acquired resistance to disease in plants. Hort. Rev., 18: 247-289.

Han, J.S.; Cheng, J.H.; Yoon, T.M.; Song, J.;Rajkarnikar,A.; Kim, W.G.;Yoo, I.D.; Yang, Y.Y. and Suh, J. W. 2005. Biological control agent of common scab disease by antagonistic strain Bacillus sp. Sunhua. J. Appl. Microbiol., 99:213-221.

Hassan, M.M.E. 2013. Studies on Rhizoctonia Canker and Black Scurf Disease of Potato. Ph.D. Thesis, Plant Pathol. Dept., Fac. Agric., Assiut Univ., 161 p.

Hawksworth, D.L and Talboys,P.W. 1970. Verticillium dahliae. CMI Descriptions of Pathogenic Fungi and Bacteria No. 256. CAB

Horst, K.R. 1983. Compendium of Rose Diseases. The American Phytopathological Society. St. Paul, Minnesota. USA.pp:1-50.

Lacicowa, B. and Pieta, D. 1996. The efficiency of microbiological dressing of pea seeds (PisumsativumL.) against pathogenic soil borne fungi. RocznikiNaukRolniczych. Seria E., OchronaRoslin,25(112): 15-21. (Cited from Ragabet al., 1999).

Locke,J.C.;Marois, J.J. and Papavizas, G.C.1985. Biological control of Fusariumwilt of greenhouse grown chrysanthemums. Plant Dis., 69: 167-169.

Maruthachalam, K.; Klosterman, S.J.; Kang,S.; Hayes, R.J. and Subbarao, K.V. 2011.Identification of pathogenicity-related genes in thevascular wilt fungus Verticilliun dahliae by Agrobacterium tumefaciens-mediated T-DNA insertional mutagenesis. Mol. Biotechnol., 49(3): 209-221.

Papavizas, G.C. 1982. Survival of Trichoderma harzianumin soil and in pea and bean rhizospheres. Phytopathology, 72: 121-125.

Ragab, M.M.; Aly, M.D.H.;Ragab,Mona M.M. and El-Mougy, Nehal S. 1999. Effect of fungicides, biocides and bioagents on controlling of pea root-rot disease. Egypt. J. Phytopathol., 27: 65-81.

Egypt. J. Phytopathol., Vol. 44, No. 2(2016) 
Ragab,Mona M.M.; Saber, M.M.; El-Morsy, S.A. and Abdel-Aziz,AbeerR.M. 2009. Induction of systemic resistance against root rot of basil using some chemical inducers. Egypt. J. Phytopathol.,37 (1):59-70.

Rojo, F.G.; Reynoso, M.M.; Sofia, M. and Chulzel,F. 2007. Biological control by Trichoderma species of Fusarium solanicausing peanut brown root rot under field conditions. Crop. Protec., 26: 549-555.

Salamone, A.; Scarito, G.; Pane, A. and Cacciola, S.O. 2011. Root and basal stem rot of rose caused by Phytophthora citrophthora in Italy. Plant Dis.,95(3): 358-360.

Sallam, A.A.; Abdel Razik, A.A. and Rushdi, M.H. 1978. Antagonistic effect of Bacillussubtilisagainst Cephalosporium maydis. Egypt. J. Phytopathol., 10: 97-105.

Seema, M. and Devaki, N.S.2012. In vitro, evaluation of biological control agents against Rhizoctonia solani.J. of Agric. Technol., 8 (1): 233- 240.

Snedecor, G.W. and Cochan, C.G. 1982. Statestical Methods, $6^{\text {th }}$ ed. Iowa State University, Press Ames, Iowa, USA.

Singh, A.; Phougat, N.; Kumar, M. and Chhillar, A. 2013. Antifungal proteins: potent candidate for inhibition of pathogenic fungi. Current Bioact. Comp., 9:101-112.

Sunick, K.;Sungioon, Y. and Honggi,K. 1997. Selection of antagonistic bacteria for biological control of ginseng diseases. Kor. J. of Plant Pathol., 13: 342-348.

Woodward, J.E. and Wheeler, T.A. 2011. Integrated Management of Verticillium Wilt in Cotton. AgriLIFE Extension Service, Texas, USA.

Zahra A.M.K. 1990. Studies on wilt disease of seasame (SesamumindicumL.) in Upper Egypt. Ph.D. Thesis, Plant Pathol. Dept., Fac. Agric., Assiut Univ., $140 \mathrm{p}$.

Ziadi,S.;Barbedette, S.;Godard, J.F.; Monot, C.;Corre, D.L.E.,Silue,D. and Le Corre,L. 2001. Production of pathogenesis-related proteins in the cauliflower (Brassica oleraceavar. botrytis) downy mildew (Peronosporaparasitica) pathosystemtreated with acidbenzolar-s methyl. Plant Pathol.,50(5): 579586. 

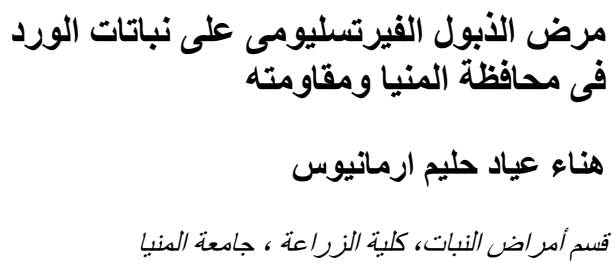

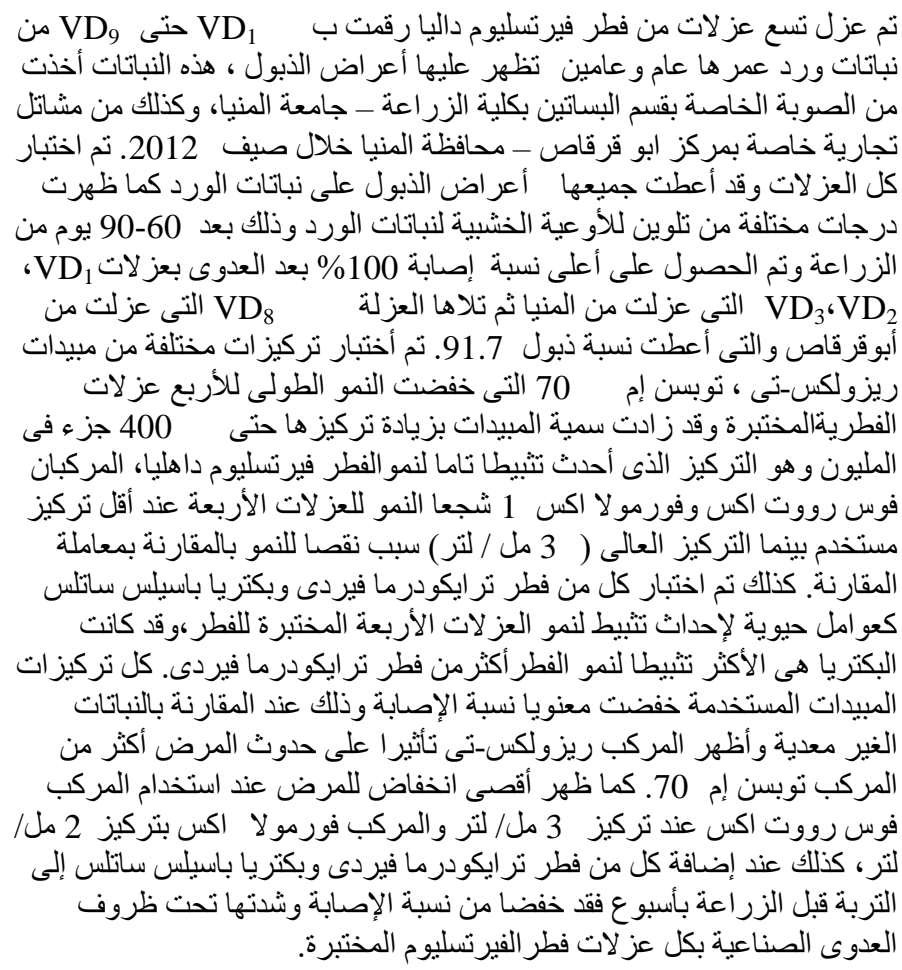

Egypt. J. Phytopathol., Vol. 44, No. 2(2016) 